2 Siddiqui explains Muslims' lack of engagement with wider society as follows: 'It is the fear of losing our faith and being assimilated that paralyses Muslims from getting involved in the mainstream community and to work towards improving society in general' (p. 190). determined to maintain an Islamic identity in secular societies and: '... [to] resist the powerful, centripetal force of assimilation' (Bullock: p. xv). This attitude influences both the private and public spheres. Shamma states: 'One of the most important jobs of Muslim parents is to immerse their children in an Islamic environment. ... We did whatever was necessary to make sure our children had good Muslim friends. ... We made friends with people because they had children who practiced Islamic behaviour' (pp. 170-171). And in work with secular or interfaith institutions, furthering the cause of Islam and Muslims is prioritized; Farooqi says: 'I believe forming Muslim clubs is an excellent way to spread the message of Islam ... and to spread the word is our job' (p. 77) and Rahman suggests: '.. like bricks in a wall, believers surround, support, and strengthen each other to create a strong unified barrier to external forces' (p. 138). She emphasizes the importance of: '.. working together to educate the larger community about Islam, our beliefs and practices, as well as to work within the various systems to accommodate ... Islamic practices' (p. 139).

This book provides an important counterbalance to stereotypes of Islam as a violent religion that renders women subservient to men. Whether it has achieved its aim of opening dialogue between mainstream societies and Muslims is more debatable. For only one writer, Shahina Siddiqui, adopts an inclusive approach: 'I believe that we cannot be isolationist in our activism since the world is one, humanity is one, and what affects others affects me as well' (p. 190). ${ }^{2}$ Despite their impressive work, most of the other writers seem to define activism in ways that exclude non-Muslims and prohibit the two-way interaction that is arguably a pre-requisite of dialogue - and this is surely a loss for us all.

Marie Macey

doi:10.1057/palgrave.fr. 9400390

\section{Feminist politics, activism and vision: local and global challenges}

Luciana Ricciutelli, Angela Miles and Margaret McFadden (editors); Zed Books, London and New York, 2005, 320p, ISBN 1-84277-350-X, £55.00 (Hbk); ISBN 1-84277-351-8, £17.95 (Pbk)

Luciana Ricciutelli, Angela Miles and Margaret McFadden have compiled a refreshingly diverse array of papers from twenty activists, scholars and policymakers who attempt to answer the question of how contemporary feminism can sustain its efforts in the face of 'neo-liberal globalization and religious fundamentalisms' (p. 9). Accessible to a range of readers, this project contributes to the dynamic debates around whether women's activism and its 
increasing interaction with states and non-governmental organizations (NGOs) depoliticize its feminist agenda, or whether these evolving relationships reinvigorate its cause.

Organized into five sections, the book's essays are arranged by economic context, strategy, struggles and challenges. In the first section, Vandana Shiva and Arlie Russell Hochschild posit the production of food and caring, respectively, as 'universal' currencies through which women's activism is fueled, yet which remain undervalued by neo-liberalism's proponents. While these essays provide a clue to the economic context that grounds the diverse struggles portrayed in the remainder of the book, they can be read as values that underpin women's struggles. Although an introduction to these values is important, the actual analysis of the economic context of activism seems slightly less than robust. Consequently, this leaves relatively few options for consideration when trying to decide 'what value basis can best ground feminist visions and feminist movement?' (p. 14). However, articles in the second section - such as Nighat Said Khan's forceful essay on how the state's co-optation of women's networks has deradicalized feminism in Pakistan, and Lenore Lyon's sobering account of the Singaporean state's resistance to civic activity and, by proxy, transnational activism around domestic workers' rights, add to the book's useful contribution to debates exploring relationships between women's activism and liberal democratic institutions. Also highlighted in this section is the way in which successful feminist strategies, such as networking, have advanced women's issues in policy arenas.

Several authors provide refreshing accounts of local struggles that have been fought during relatively short periods of time, as in the engaging article on women's activism around oil production in Nigeria by Terisa $\varepsilon$. Turner and Leigh S. Brownhill, or intermittently throughout longer periods, as in Bina D'Costa's compelling paper which documents how women's accounts of history were subsumed by more nationalist accounts. Issues including the production and sale of crude oil, prices of meat and milk, prohibition against arrack (liquor), constructions of history omitting women's accounts of rape, as well as struggles between men and women in religious groups over the latter's participation in feminist movements, all foreground the far-reaching effects of building alliances locally and globally. The impact of women's activism on other civil society actors and how those actors engaged with or resisted feminist ideologies is laid out in the book's third section. Conversely, it is evident in the fourth section that issues such as leadership, nationalism and citizenship pose challenges to women's activism rather than contributing to its source of power. For example, lawyer and activist, Sylvia Tamale argues that the recent increase in women's political participation in several African countries in the last decade is still framed by political leadership styles, such as autocracy or militarism, which are predicated on women's domesticity and exclusion. To redress this, she offers alternative models of leadership which would 
democratize public spaces through certain legal and institutional changes, including institutionalizing gender into public institutions (p. 322).

The book's major strength is its balance between contemporary and historical analysis. Published in the middle of this decade, the book offers a well-timed yet interminable interrogation of transfeminist theory and practice. The book's timeliness lies in its origins. Its conception during a workshop of feminist journal editors coincided with the extinguishing of lives in the Twin Towers of the World Trade Centre in New York on 11 September 2001. Birthed in the aftermath of death and destruction, the questions posed in this volume published four years later still seem relevant. In fact the book escapes obsoleteness and embarks on a vital journey of self-reflection by learning from geographic or historical differences within the transfeminist movement to examine ways in which women struggle against structural, economic, political, institutional and practical challenges in their socio-historical context. By embarking on this journey of reflection, the book wades uncertainly toward answering queries Angela Miles situates in the socio-political context of globalization and its subsequent militarization, but it does ultimately address them. However, the book's chronicles of struggles, summed up in Alda Facio's lyrical conclusion, uphold feminist values such as solidarity and peace as strategies against globalization. Overall, the editors' careful selection of essays from authors with vast and varied experiences creates a juxtaposition which allows the book to escape the traps of reactive engagement with the pervasive discourse of 'anti-terrorism', thus providing an enjoyable read that will interest academics, activists, and advocates alike.

doi: $10.1057 /$ palgrave.fr. 9400402

Chinwe Madubuike

\section{Women making news: gender and the women's periodical press in Britain}

Michelle Elizabeth Tusan; University of Illinois Press, Champaign, IL, USA, 2005, 320p, ISBN 0-252-03015-X, \$45 (Hbk, in USD)

The story of the women's advocacy press in Britain may be one of 'a series of failed experiments' ( $p .243$ ). Yet Michelle Tusan's analysis of these repeated efforts is not in vain, as it adds depth to our understandings of the connections between activist women from the mid-nineteenth to the mid-twentieth century. It documents the persistent attempts made by women to create an imagined community of their own through the printed word. It also traces the real-world development of the women's press as an industry and alternative infrastructure, which took advantage of new technologies and modes of economic organization 